\title{
International Review
}

\section{of the Red Cross}

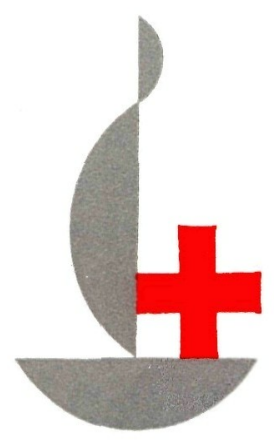

$\left.\begin{array}{l}\text { CENTENARY YEAR } \\ \text { OF THE RED CROSA }\end{array}\right] 962$

GENEVA

INTERNATIONAL COMMITTEE OF THE RED CROSS FOUNDED IN 1863 


\section{INTERNATIONAL COMMITTEE OF THE RED CROSS}

LEOPOLD BOISSIER, Doctor of Laws, Honorary Professor at the University of Geneva, former Secretary-General to the Inter-Parliamentary Union, President (member since 1946)

JACQUES CHENEVIERE, Hon. Doctor of Literature, Honorary Vice-President (1919)

CARL J. BURCKHARDT, Doctor of Philosophy, former Swiss Minister to France (1933)

MARTIN BODMER, Hon. Doctor of Philosophy, Vice-President (1940)

ERNEST GLOOR, Doctor (1945)

PAUL RUEGGER, former Swiss Minister to Italy and the United Kingdom, Member of the Permanent Court of Arbitration (1948)

RODOLFO OLGIATI, Hon. Doctor of Medicine, former Director of the Don Suisse (1949)

MARGUERITE VAN BERCHEM, former Head of Section, Central Prisoners of War Agency (1951)

FRÉDERIC SIORDET, Lawyer, Counsellor of the International Committee of the Red Cross from 1943 to 1951 , Vice-President (1951)

GUILLAUME BORDIER, Certificated Engineer E.P.F., M.B.A. Harvard, Banker (1955)

ADOLPHE FRANCESCHETTr, Doctor of Medicine, Professor of clinical ophthalmology at Geneva University (1958)

HANS BACHMANN, Doctor of Laws, Assistant Secretary-General to the International Committee of the Red Cross from 1944 to 1946 (1958)

JACQUES FREYMOND, Doctor of Literature, Director of the Graduate Institute of International Studies, Professor at the University of Geneva (1959)

DIETRICH SCHINDLER, Doctor of Laws (1961)

SAMUEL GONARD, former Colonel Commanding an Army Corps, former Professor at the Federal Polytechnical School (1961)

HANS MEULI, Doctor of Medicine, Brigade Colonel, former Director of the Swiss Army Medical Service (1961)

MARJORIE DUVILLARD, Directress of " Le Bon Secours " Nursing School (1961)

MAX PETITPIERRE, Doctor of Laws, former President of the Swiss Confederation (1961)

\section{Honorary members :}

Miss LUCIE ODIER, Honorary Vice-President; Messrs. FRÉDERIC BARBEY and Paul CARRY, Miss SUZANNe FERriERE, Messrs. EDOUARD de HALLER, PAUL LOGOZ, ALFREDO VANNOTTI, ADOLF VISCHER.

Direction: ROGER GALLOPIN, Doctor of Laws, Executive Director JEAN S. PICTET, Doctor of Laws, Director for General Affairs CLAUDE PILLOUD, Deputy Director for General Affairs 


\title{
INTERNATIONAL REVIEW \\ OF THE RED CROSS
}

THIRD YEAR - No. 32

NOVEMBER 1963

*

$\operatorname{CONTENTS}$

\begin{abstract}
A great anniversary . . . . . . . . . . . . . . . . . . . 569
Centenary Congress of the International Red Cross - Resolutions
\end{abstract} adopted by the Council of Delegates . . . . . . . . . . . . 573

INTERNATIONAL COMMITTEE OF THE RED CROSS

The Nobel Peace Prize Award to the ICRC and the League . . . 599

News Items . . . . . . . . . . . . . . . . . . . . . . . 601

$\dagger$ †rs R.-M. Frick-Cramer . . . . . . . . . . . . . . . . 604

History of the International Committee. . . . . . . . . . . . 606

\section{INTERNATIONAL RED CROSS}

Meeting and exchanges on the occasion of the Red Cross Centenary 607

\section{MISCELLANEOUS}

The education of blind youth . . . . . . . . . . . . . 617 


\section{FRENCH EDITION OF THE REVIEW}

The French edition of this Review is issued every month under the title of Revue internationale de la Croix-Rouge. It is, in principle, identical with the English edition and may be obtained under the same conditions.

\section{SUPPLEMENTS TO THE REVIEW}

SPANISH

Congreso del Centenario de la Cruz Roja Internacional - Resoluciones adoptadas por el Consejo de Delegados.

\section{GERMAN}

Ein grosser Jahrestag. - Kongress der Hundertjahrfeier des Internationalen Roten Kreuzes. - Der Friedensnobelpreis für das Internationale Komitee und die Liga.

THE

INTERNATIONAL REVIEW OF THE RED CROSS

is published each month by the International Committee of the Red Cross

7, Avenue de la Paix, Geneva, Switzerland Postal Cheque No. I. 1767

Annual subscription : Sw. fr. $25 .-(\$ 6)$

Single copies Sw. fr. 2.50 (\$0.60)

Editor: JEAN-G. LOSSIER 